\title{
PROPERTI MEKANIK BETON RINGAN DENGAN MENGGUNAKAN AGREGAT BATU APUNG SERTA ABU TERBANG SEBAGAI PENGGANTI SEBAGIAN SEMEN PORTLAND DAN SUPERPLASTICIZER
}

\author{
I Gusti Agung Neny Purnawirati ${ }^{1}$, I M. Alit K. Salain ${ }^{2}$, dan Dharma Putra ${ }^{2}$
}

\begin{abstract}
Abstrak Penelitian mengenai beton ringan dengan batu apung yang selama ini dilakukan, masih memiliki kekurangan terutama pada kuat tekan. Umumnya penelitian mengenai beton ringan dengan batu apung yang menggunakan semen Portland memberikan hasil kuat tekan berkisar 13,5-16,8 MPa. Untuk mengurangi penggunaan semen, perlu dicari bahan alternatif untuk mengganti sebagian semen Portland yang sekaligus dapat meningkatkan kuat tekan. Selain itu, untuk meningkatkan kuat tekan perlu digunakan air pengaduk yang rendah. Namun, dengan penggunaan air pengaduk yang rendah, maka pengerjaan cukup sulit dilakukan sehingga diperlukan superplasticizer untuk memudahkan pengerjaan.

Penggantian semen dengan abu terbang mulai dari 0\%, 10\%, 20\%, 30\% dan 40\%. Perbandingan berat semen : pasir : batu apung yang digunakan adalah $1,00: 3,07: 1,14$ dengan nilai fas 0,32 mengacu pada SNI 03-3449-2002. Penelitian ini menggunakan superplasticizer sebesar 0,4\% dan 0,8\% dari berat semen yang ditambahkan pada saat pengadukan beton. Distribusi butiran pasir dan batu apung dirancang menurut SNI 03-2834-2000, yaitu gradasi zone 1 untuk pasir dan gradasi diameter maksimum 12,5 mm untuk batu apung.

Peningkatan kuat tekan dan modulus elastisitas terjadi seiring dengan bertambahnya umur hidrasi beton dari 28 hari ke 56 hari. Kuat tekan meningkat dengan bertambahnya penggantian semen Portland dengan abu terbang sampai dengan $20 \%$ dan selanjutnya menurun. Namun demikian dengan penggantian $40 \%$ semen dengan abu terbang masih dihasilkan kuat tekan yang lebih tinggi dibandingkan dengan yang tanpa abu terbang. Gejala yang relatif sama juga terjadi pada modulus elastisitas. Nilai kuat tekan dan modulus elastisitas maksimal dihasilkan pada penggantian $20 \%$ semen Portland dengan abu terbang dan 0,4\% superplasticizer berturut-turut sebesar 14,34 $\mathrm{MPa}$ dan 10766,71 MPa pada umur 28 hari dan 18,12 MPa dan 11006,56 MPa pada umur 56 hari.
\end{abstract}

Kata kunci : abu terbang, batu apung, beton ringan, kuat tekan, modulus elastisitas

\section{MECHANICAL PROPERTY OF LIGHTWEIGHT CONCRETE USING PUMICE AS A COARSE AGGREGATE, FLY ASH AS A SUBSTITUTION OF A PART OF PORTLAND CEMENT AND SUPERPLASTICIZER}

Abstract Researches about lightweight concrete that be held nowadays, have some weakness particularly in compressive strength. Usually researches about lightweight concrete with pumice that uses Portland giving result about $13,5-16,8 \mathrm{MPa}$ of compressive strength. For reducing the cement using, it is needed to find an alternative of Portland cement exchanged that improve the compressive strength at once. In addition, for compressive strength increasing it is needed to use water low water stirring. But, with a low water stirring, so mixing will be difficult for doing so it is needed superplastizer for mixing easier.

Fly ash varieties as an exchanged of a part of Portland cement start from $0 \%, 10 \%, 20 \%, 30 \%$, $40 \%$. The weight ratio of cement : sand : pumice is $1,00: 3,07: 1,14$ with factor adhesive water 0,32 refers SNI 03-3449-2002 with compressive strength of the plan is $18 \mathrm{MPa}$. This study uses superplasticizer $0,4 \%$ and $0,8 \%$ of cement weight is added during the mixing concrete. Distribution of sand and pumice designed by SNI 03-2834-2000, zone 1 for sand and graduation maximum diameter of 12,5 for pumice.

Increase compressive strength and modulus of elasticity occurred with age concrete hydration of 28 days to 56 days. Compressive strength increase with fly ash varieties as an exchanged of a part of Portland cement with fly ash until $20 \%$ and then decreasing. However, the replacement of Portland cement $40 \%$ with fly ash was produced higher compressive strength than without fly ash. A relatively same indicator be shown on modulus of elasticity that be carried out from changing of $20 \%$ Portland cement by fly ash and $40 \%$ superplasticizer consecutively as 14,34 $\mathrm{MPa}$ and $10766,71 \mathrm{MPa}$ in 28 days and $18,12 \mathrm{MPa}$ and $11006,56 \mathrm{MPa}$ in 56 days.

Keyword : fly ash, pumice, lightweight concrete, compressive strength, modulus of elasticity

\footnotetext{
${ }^{1}$ Mahasiswa Program Magister Teknik Sipil, Program Pascsarjana, Universitas Udayana, Denpasar

${ }^{2}$ Dosen Program Magister Teknik Sipil, Program Pascsarjana, Universitas Udayana, Denpasar
} 


\section{PENDAHULUAN \\ Latar Belakang}

Beton ringan merupakan beton dengan berat isi kurang dari $1900 \mathrm{~kg} / \mathrm{m}^{3}$ (SNI 032847-2002). Beton ringan dibuat dengan menggunakan agregat kasar yang bersifat ringan. Batu apung merupakan material ringan yang mempunyai berat isi antara 500-900 $\mathrm{kg} / \mathrm{m}^{3}$. Beton ringan memiliki kelemahan terutama pada kuat tekan. Penelitian mengenai beton ringan dengan agregat batu apung menunjukkan kuat tekan optimum sebesar 13,5-16,8 MPa (Akmaludin, 2009).

Batu apung merupakan material ringan yang mempunyai berat isi antara 500-900 $\mathrm{kg} / \mathrm{m}^{3}$. Oleh karena itu, material tersebut banyak dijadikan agregat kasar dalam campuran beton ringan.

Air pada pembuatan adukan beton digunakan untuk bereaksi dengan semen sehingga menghasilkan proses hidrasi. Jumlah air yang dibutuhkan untuk proses hidrasi tersebut sekitar 25\%-30\% dari berat semen. Selain itu air berfungsi untuk mempermudah sifat pengerjaan beton atau meningkatkan workability beton. Jumlah air untuk campuran beton pada umumnya dihitung berdasarkan nilai perbandingan antara berat air dan berat semen pada campuran adukan, dikenal dengan istilah faktor air semen (fas).

Dalam pembuatan beton, untuk menghasilkan kuat tekan yang tinggi diperlukan faktor air semen yang rendah. Penggunaan nilai fas yang rendah, menyebabkan kesulitan dalam pengerjaan sehingga pemadatannya menjadi tidak maksimal dan mengakibatkan beton menjadi keropos. Untuk mengatasi hal tersebut dapat dipergunakan superplasticizer yang sifatnya memperbaiki workability (dengan

menggunakan fas kecil) tetapi tetap mudah dikerjakan. Penggunaan superplasticizer telah dilakukan oleh Suseno, dkk. (2008) dimana dalam penelitian ini penambahan superplasticizer sebesar $0 \%, 0,4 \%, 0,8 \%$, $1,2 \%, \quad 1,6 \%$ terhadap berat semen menunjukkan hasil kuat tekan sebesar 20,569 MPa, 20,711 MPa, 22,366 MPa, 20,272 MPa, 19,211 MPa. Hasil penelitian menunjukkan bahwa penambahan superplasticizer akan mengakibatkan nilai slump meningkat.

Penggunaan pozzolan dalam beton juga dapat meningkatkan kuat tekan beton, karena senyawa CSH dan CAH yang dibentuk oleh pozzolan akan bereaksi dengan $\mathrm{CSH}$ dan $\mathrm{Ca}(\mathrm{OH})_{2}$ dari semen dan akan membentuk senyawa perekat tambahan berupa CSH dan CAH (Lea, 1970; Mehta, 1986; Neville and Brooks, 1998; Salain dkk, 2011). Salah satu jenis pozzolan adalah abu terbang yang merupakan hasil residu dari pembakaran batu bara. Abu terbang memiliki sifat butiran yang halus, tidak porous, dan bersifat pozzolanik. Penelitian yang dilakukan oleh Marsiano (2011) menyebutkan bahwa kuat tekan beton yang didapat dengan 3 varian campuran menghasilkan campuran beton tanpa abu terbang sebesar 40,85 $\mathrm{MPa}$, campuran abu terbang $10 \%$ dan $20 \%$ masing - masing sebesar 41,57 $\mathrm{MPa}$ dan 41,28 $\mathrm{MPa}$. Pengaruh penggunaan abu terbang dalam beton tersebut adalah butiran abu terbang yang halus membuat beton lebih padat karena rongga antara butiran agregat diisi oleh abu terbang sehingga dapat memperkecil pori - pori yang ada dan memanfaatkan sifat pozzolan dari abu terbang.

Berdasarkan uraian di atas, maka dilaksanakan penelitian untuk mendapatkan properti mekanik beton ringan dengan variasi abu terbang sebagai pengganti sebagian semen Portland menggunakan bahan tambah superplasticizer. Properti mekanik beton ringan yang akan diteliti mencakup : kuat tekan, dan modulus elastisitas.

\section{Rumusan Masalah}

1. Bagaimana peningkatan properti mekanik beton ringan dengan variasi abu terbang sebagai pengganti sebagian semen Portland dan superplasticizer?

2. Berapa persen penggunaan abu terbang yang optimal untuk menghasilkan kuat tekan dan modulus elastisitas yang maksimal ?

\section{Tujuan Penelitian}

1. Untuk mengetahui bagaimana peningkatan properti mekanik beton ringan dengan variasi abu terbang sebagai pengganti sebagian semen Portland dan superplasticizer

2. Untuk mengetahui berapa penggunaan abu terbang yang optimal untuk menghasilkan kuat tekan dan modulus elastisitas yang maksimal. 
Manfaat Penelitian

1. Manfaat akademik yaitu, mengembangkan teknologi bahan bangunan khususnya beton ringan berbasis material alam.

2. Manfaat praktis yaitu, dapat merumuskan campuran adukan beton ringan dengan menggunakan agregat kasar berupa batu apung serta abu terbang sebagai pengganti sebagian semen dan superplasticizer yang divariasikan, serta menghasilkan beton ringan dengan tujuan struktural.

\section{KAJIAN PUSTAKA \\ Pengertian Beton}

Beton merupakan campuran antara semen Portland atau semen hidrolik, agregat halus, agregat kasar dan air, dengan atau tanpa bahan tambahan yang membentuk masa padat (SNI 03-2847-2002)

\section{Agregat Ringan}

Agregat ringan merupakan agregat yang dalam keadaan kering dan gembur mempunyai berat isi sebesar $1100 \mathrm{~kg} / \mathrm{m}^{3}$ atau kurang (SNI 03-2847-2002). Secara struktural pertimbangan penggunaan agregat ringan didasarkan atas berat volume atau kepadatan dari beton yang terbentuk dimana akan lebih ringan dibandingkan menggunakan agregat normal.

\section{Beton Ringan}

Beton ringan adalah beton yang mempunyai berat satuan tidak lebih dari 1900 $\mathrm{kg} / \mathrm{m}^{3}$ (SNI 03-2847-2002). Beton ringan dapat diperoleh dengan membuat beton dari agregat ringan, penambahan udara, atau penambahan material yang mempunyai berat satuan yang kecil.

\section{Bahan Tambah}

Bahan tambah merupakan material selain air, agregat dan semen hidrolik yang dicampurkan dalam beton atau mortar yang ditambahkan sebelum atau selama pengadukan berlangsung. Bahan tambah digunakan untuk memodifikasi sifat dan karakteristik dari beton, misalnya untuk dapat dengan mudah dikerjakan serta penghematan energi. Menurut Mulyono (2003), secara umum bahan tambah yang digunakan dalam beton dapat dibedakan menjadi dua, yaitu bahan tambah yang bersifat mineral (additive) dan bahan tambah yang bersifat kimiawi (chemical admixture). Bahan tambah admixture ditambahkan saat pengadukan atau saat pelaksanaan pengecoran (placing) sedangkan bahan tambah additive yang bersifat mineral ditambahkan saat pengadukan dilaksanakan.
Superplasticizer adalah zat - zat polimer organik yang dapat larut dalam air yang telah disatukan dengan menggunakan proses polimerisasi yang komplek untuk menghasilkan molekul - molekul panjang dari masa molekular yang tinggi. Molekul molekul panjang ini akan membungkus diri mengelilingi partikel semen dan memberikan pengaruh negatif yang tinggi sehingga antar partikel semen akan saling menjauh dan menolak. Hal ini akan menimbulkan pendispersian partikel semen sehingga mengakibatkan keenceran adukan dan meningkatkan workability. Perbaikan workability ini dapat dimanfaatkan untuk menghasilkan beton dengan workability yang tinggi atau menghasilkan beton dengan kuat tekan yang tinggi.

Abu terbang (fly ash) adalah material yang berasal dari sisa pembakaran batu bara yang tidak terpakai. Pembakaran batu bara kebanyakan digunakan untuk Pembangkit Listrik Tenaga Uap. Sekitar 75 - 90\% abu terbang yang keluar dari cerobong asap dapat ditangkap oleh sistem elekrostatik precipitator. Sisa yang lain didapat di dasar tungku (bottom ash). Material ini mempunyai kadar bahan semen yang tinggi dan mempunyai sifat pozzolanik. Kandungan abu terbang sebagian besar terdiri dari silikat dioksida $\left(\mathrm{SiO}_{2}\right)$, aluminium $\left(\mathrm{Al}_{2} \mathrm{O}_{3}\right)$, besi $\left(\mathrm{Fe}_{2} \mathrm{O}_{3}\right)$, dan kalsium $(\mathrm{CaO})$, serta magnesium, potassium, sodium, titanium, dan sulfur dalam jumlah yang sedikit. Penggunaan abu terbang dalam campuran beton mempunyai beberapa keunggulan, yaitu :

- Untuk beton segar

- Kehalusan dan bentuk partikel abu terbang yang bulat dapat meningkatkan workability.

- Mengurangi terjadinya bleeding dan segragasi.

- Untuk beton keras

- Kontribusi peningkatan kuat tekan beton pada umur 52 hari.

- Meningkatkan durabilitas beton.

- Meningkatkan kepadatan (density)

Abu terbang (fly ash) dapat meningkatkan kuat tekan beton, karena abu terbang mengandung $\mathrm{SiO}_{2}$ yang tinggi, kekuatan beton meningkat karena butiran mikrosilika yang sangat halus bereaksi dengan air dan $\mathrm{Ca}(\mathrm{OH})_{2}$ (kapur) akan menghasilkan massa yang padat, sehingga menghasilkan kuat tekan yang tinggi (Hidayat, 2003). 
Pada saat hidrasi semen dan pozzolan terjadi dua tahap reaksi yaitu reaksi primer berupa pembentukan $\mathrm{C}-\mathrm{S}-\mathrm{H}$ oleh semen kemudian dilanjutkan dengan reaksi sekunder berupa pengikatan $\mathrm{Ca}(\mathrm{OH})_{2}$ oleh silica aktif dari bahan pozzolan membentuk $\mathrm{C}-\mathrm{S}-\mathrm{H}$. umunya reaksi sekunder terjadi setelah umur 28 hari. Hal ini disebabkan karena kehadiran pozzolan menghambat proses hidrasi pada umur awal (PEDC, 1987), sehingga proses pengerasan yang terjadi belum sempurna (Salain, 2007).

Reaksi mineral utama semen Portland, yaitu trikalsium silikat $\left(\mathrm{C}_{3} \mathrm{~S}\right)$ dan dikalsium silikat $\left(\mathrm{C}_{2} \mathrm{~S}\right)$ yang jika bereaksi dengan air $\left(\mathrm{H}_{2} \mathrm{O}\right)$ akan menghasilkan $\mathrm{CSH}$ dan kapur bebas $\left(\mathrm{Ca}(\mathrm{OH})_{2}\right)$. Kapur bebas tersebut tidak banyak memberikan kontribusi terhadap kuat tekan beton dan cenderung merugikan dari sisi keawetan apabila dalam perjalanan waktu kapur bebas tersebut bereaksi dengan unsur yang bersifat agresif seperti sulfat (Lea, 1970; Mehta, 1986; Neville and Brooks, 1998; Salain, 2011).

Sebagian besar komposisi kimia dari abu terbang tergantung tipe batu bara. Jenis abu terbang dibedakan menjadi 3 jenis, yaitu :

- Kelas C, yang merupakan abu terbang yang mengandung $\mathrm{CaO}$ di atas $10 \%$ yang dihasilkan dari pembakaran lignite atau sub-bitumen batubara (batu bara muda). Kadar yang terdapat sebagai berikut :

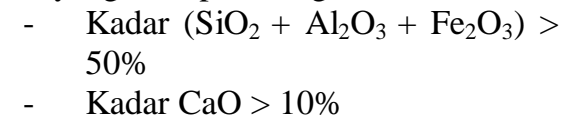

- Kelas F, yang merupakan abu terbang yang mengandung $\mathrm{CaO}$ lebih kecil dari $10 \%$ yang dihasilkan dari pembakaran anthracite atau bitumen batu bara. Kadar yang terdapat sebagai berikut :

$$
\begin{array}{ll}
- & \text { Kadar }\left(\mathrm{SiO}_{2}+\mathrm{Al}_{2} \mathrm{O}_{3}+\mathrm{Fe}_{2} \mathrm{O}_{3}\right)> \\
& 70 \% \\
-\quad & \text { Kadar } \mathrm{CaO}<10 \%
\end{array}
$$

- Kelas N, yang merupakan pozzolan alam atau hasil pembakaran yang dapat digolongkan antara lain : tanah diatomic, opaline chertz, dan shales, tuff dan abu vulkanik yang biasa diproses melalui pembakaran atau tidak melalui proses pembakaran. Selain itu juga mempunyai sifat pozzolan yang baik.

\section{Kuat Tekan}

Kuat tekan dinotasikan dengan $\mathrm{f}_{\mathrm{C}}$, yaitu tegangan tekan maksimum yang didapatkan melalui tata cara pengujian standar, menggunakan mesin uji dengan cara memberikan beban bertingkat dengan kecepatan peningkatan beban tertentu pada benda uji silinder sampai hancur.

Tegangan tekan maksimum $\mathrm{f}_{\mathrm{C}}$ diberikan persamaan berikut :

$$
\mathrm{f}_{\mathrm{C}}=\frac{\mathrm{P}}{\mathrm{A}}
$$

dengan :

$\mathrm{f}_{\mathrm{C}}=$ Kuat tekan $(\mathrm{MPa})$

$\mathrm{P}=$ Beban maksimum $(\mathrm{N})$

$\mathrm{A}=$ Luas bidang maksimum $\left(\mathrm{mm}^{2}\right)$

\section{Modulus elastisitas beton}

Pada umumnya bahan, termasuk beton memiliki daerah awal pada diagram tegangan regangannya dimana bahan berkelakuan secara elastis dan linier. Kemiringan diagram tegangan regangan dalam daerah elastis linier itulah yang dinamakan modulus elastisitas.

$$
\mathrm{E}_{\mathrm{C}}=\frac{\mathrm{S}_{2}-\mathrm{S}_{1}}{\varepsilon_{2}-0,00005}
$$

dengan :

$$
\begin{aligned}
\mathrm{E}_{\mathrm{C}}= & \text { modulus elastisitas beton }(\mathrm{MPa}) \\
\mathrm{S}_{2}= & \text { tegangan sebesar } 40 \% \text { tegangan } \\
& \text { ultimitnya }(\mathrm{MPa}) \\
\mathrm{S}_{1}= & \text { tegangan beton pada saat regangan } \\
& \text { mencapai } 0,00005(\mathrm{MPa}) \\
\varepsilon_{2}= & \text { regangan yang terjadi pada saat } \\
& \text { tegangan mencapai } \mathrm{S}_{2}
\end{aligned}
$$

\section{METODE PENELITIAN Rancangan Penelitian}

Dalam penelitian ini direncanakan dengan cara uji laboratorium terhadap material batu apung, pasir, air, serta abu terbang sebagai pengganti sebagian semen dan superplasticizer. Dimana penggunaan superplasticizer sebesar $0,4 \%$ dan $0,8 \%$ terhadap berat semen, sedangkan abu terbang digunakan sebagai pengganti sebagian semen Portland dengan persentase $0 \%, 10 \%, 20 \%$, $30 \%$, dan $40 \%$. Pembuatan benda uji menggunakan silinder dengan ukuran diameter $150 \mathrm{~mm}$ dan tinggi $300 \mathrm{~mm}$.

\section{Lokasi dan Waktu Penelitian}

Penelitian ini dilakukan di Laboratorium Teknologi Bahan Jurusan Teknik Sipil Fakultas Teknik Universitas Udayana. Waktu yang diperlukan dalam penelitian ini adalah 56 hari. 


\section{Ruang Lingkup Penelitian}

Ruang lingkup yang akan diteliti adalah penggunaan abu terbang sebagai pengganti sebagian semen Portland yang divariasikan, serta menggunakan $0,4 \%$ dan $0,8 \%$ superplasticizer terhadap berat semen. Beton yang diteliti adalah beton tanpa tulangan. Benda uji untuk masing - masing perlakuan sebanyak 3 (tiga) buah dengan 2 kali pengulangan. Total keseluruhan benda uji adalah 120.

\section{Penentuan Sumber Data}

Sumber material :

1. Agregat kasar berupa batu apung yang diambil dari desa Ijo Balit Kabupaten Lombok Timur.

2. Agregat halus berupa pasir alam.

3. Semen Portland tipe 1

4. Abu terbang berasal dari PLTU Muara Enim - Palembang

5. Air PDAM.

6. Superplasticizer jenis viscocrete $3115 \mathrm{~N}$

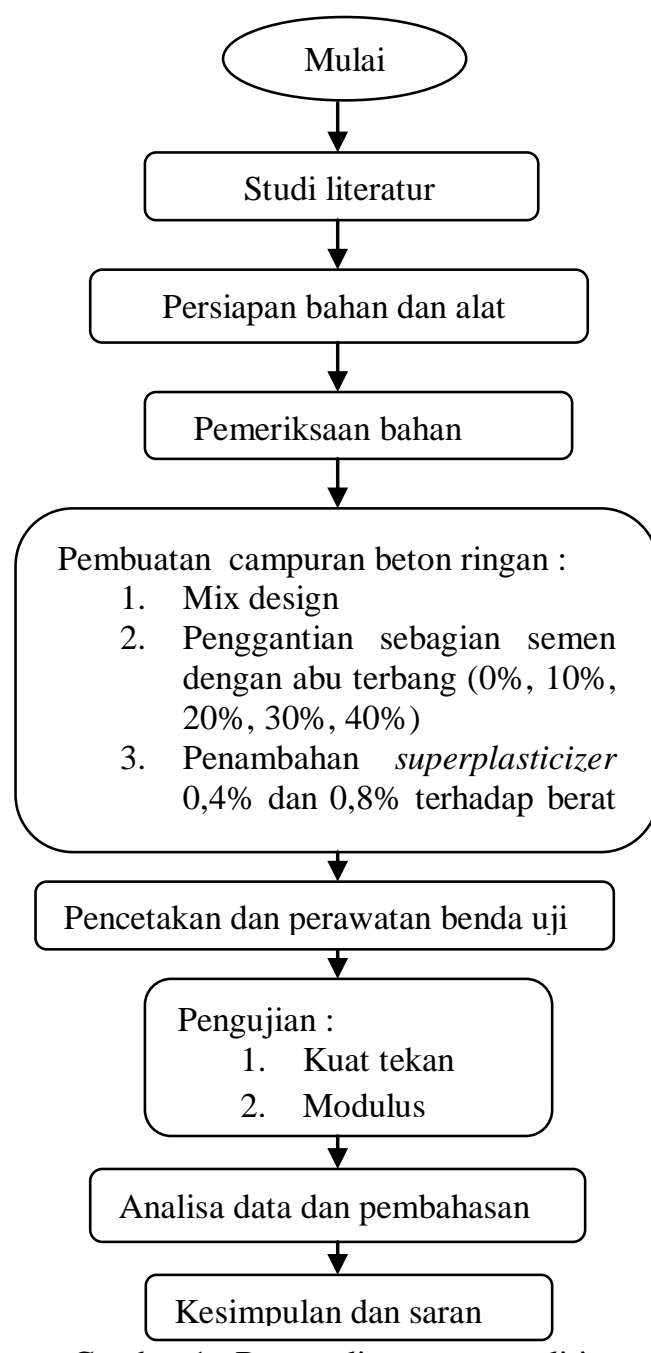

Gambar 1 . Bagan alir proses penelitian

\section{HASIL DAN PEMBAHASAN}

Pengujian slump beton segar

Pengujian nilai slump dimaksudkan untuk mengetahui tingkat kekentalan dari adukan beton yang selanjutnya dapat menggambarkan workabilitas dari campuran beton. Hasil pengujiannya dapat dilihat pada Tabel 1 dan Gambar 2.

Tabel 1 Slump beton

\begin{tabular}{|c|c|c|}
\hline $\begin{array}{c}\text { Penggantian abu } \\
\text { terbang }\end{array}$ & $0,4 \% \mathrm{SP}$ & $0,8 \% \mathrm{SP}$ \\
\hline $0 \% \mathrm{FA}$ & $100 \mathrm{~mm}$ & $118 \mathrm{~mm}$ \\
\hline $10 \%$ FA & $103 \mathrm{~mm}$ & $120 \mathrm{~mm}$ \\
\hline $20 \%$ FA & $109 \mathrm{~mm}$ & $124 \mathrm{~mm}$ \\
\hline $30 \%$ FA & $112 \mathrm{~mm}$ & $128 \mathrm{~mm}$ \\
\hline $40 \%$ FA & $115 \mathrm{~mm}$ & $132 \mathrm{~mm}$ \\
\hline
\end{tabular}

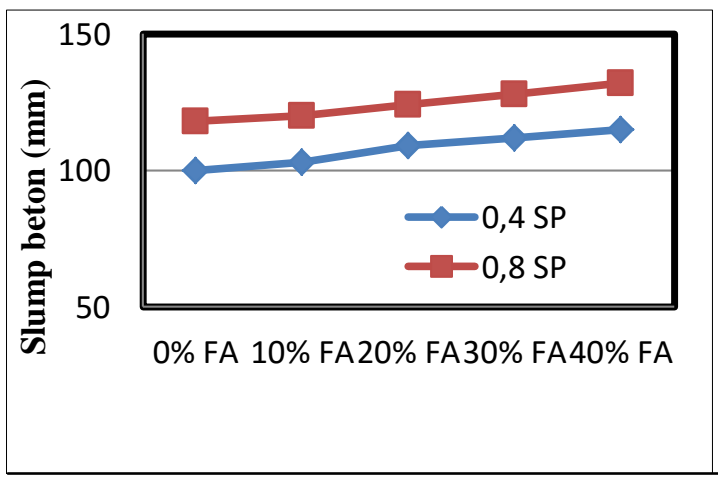

Gambar 2. Slump beton dengan penggantian abu terbang dan superplasticizer

Pada penelitian ini terlihat bahwa semakin besar penggantian semen Portland dengan abu terbang, maka slump beton segar yang dihasilkan juga meningkat. Peningkatan yang terjadi cenderung relatif sama, sehingga jika digambar dalam bentuk grafik akan membentuk garis linier seperti pada Gambar 2.

Nilai slump beton mengalami peningkatan dari penambahan $0,4 \%$ superplasticizer ke $0,8 \%$ superplasticizer. Hal ini menunjukkan bahwa semakin besar penggunaan superplatiscizer, maka slump yang dihasilkan pun akan semakin meningkat, namun dengan peningkatan nilai slump yang kurang lebih sama untuk setiap penambahan abu terbang.

Pada persentase $0 \%$ abu terbang hinggga $40 \%$ abu terbang dengan $0,4 \%$ superplatiscizer, slump mengalami peningkatan dari $100 \mathrm{~mm}$ ke $115 \mathrm{~mm}$. Demikian juga pada persentase $0 \%$ abu terbang hinggga $40 \%$ abu terbang dengan 0,8 superplatiscizer, slump meningkat dari 118 mm ke $132 \mathrm{~mm}$. 
Tabel 2. Kuat tekan beton rata - rata

\begin{tabular}{|c|c|c|c|c|c|}
\hline Perlakuan Beton & $\begin{array}{c}28 \\
\text { hari } \\
(\mathrm{MPa})\end{array}$ & $0 \% \mathrm{FA}$ & $\begin{array}{c}56 \\
\text { hari } \\
(\mathrm{MPa})\end{array}$ & $0 \% \mathrm{FA}$ & $\begin{array}{c}\% \\
\text { umur } \\
28 \mathrm{ke} \\
56\end{array}$ \\
\hline $0 \% \mathrm{FA}+0,4 \% \mathrm{SP}$ & 12,64 & 0 & 16,04 & 0 & $26,89 \%$ \\
\hline $10 \% \mathrm{FA}+0,4 \% \mathrm{SP}$ & 13,77 & $8,93 \%$ & 17,36 & $8,22 \%$ & $26,07 \%$ \\
\hline $20 \% \mathrm{FA}+0,4 \% \mathrm{SP}$ & 14,34 & $13,45 \%$ & 18,12 & $11,97 \%$ & $26,35 \%$ \\
\hline $30 \% \mathrm{FA}+0,4 \% \mathrm{SP}$ & 14,15 & $11,94 \%$ & 17,18 & $7,10 \%$ & $21,41 \%$ \\
\hline $40 \% \mathrm{FA}+0,4 \% \mathrm{SP}$ & 13,40 & $6,01 \%$ & 16,42 & $2,36 \%$ & $22,53 \%$ \\
\hline $0 \% \mathrm{FA}+0,8 \% \mathrm{SP}$ & 12,07 & 0 & 14,53 & 0 & $20,38 \%$ \\
\hline $10 \% \mathrm{FA}+0,8 \% \mathrm{SP}$ & 13,21 & $9,44 \%$ & 16,04 & $10,39 \%$ & $21,42 \%$ \\
\hline $20 \% \mathrm{FA}+0,8 \% \mathrm{SP}$ & 13,97 & $15,74 \%$ & 16,23 & $11,70 \%$ & $16,17 \%$ \\
\hline $30 \% \mathrm{FA}+0,8 \% \mathrm{SP}$ & 12,64 & $4,72 \%$ & 15,47 & $6,46 \%$ & $22,38 \%$ \\
\hline $40 \% \mathrm{FA}+0,8 \% \mathrm{SP}$ & 12,27 & $1,65 \%$ & 15,09 & $3,85 \%$ & $22,18 \%$ \\
\hline
\end{tabular}

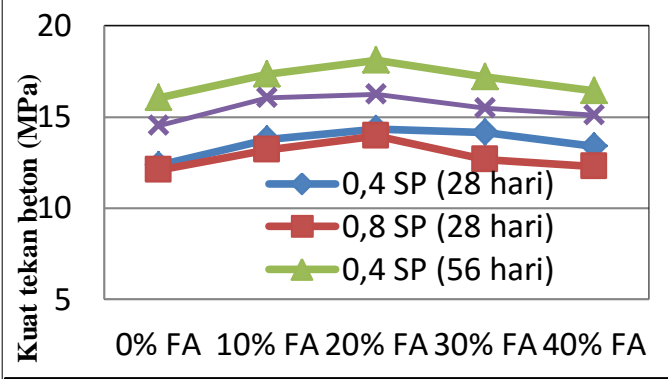

Gambar 3. Kuat tekan beton ringan dengan penggantian semen Portland dengan abu terbang

Dari Tabel 2 dan Gambar 3 terlihat bahwa, kuat tekan beton ringan mengalami peningkatan dengan bertambahnya penggantian semen Portland dengan abu terbang. Peningkatan terjadi hingga penggantian 20\% semen Portland dengan abu terbang. Penggantian semen Portland dengan abu terbang di atas $20 \%$, menyebabkan kuat tekan beton ringan mengalami penurunan terhadap kuat tekan dengan penggantian $20 \%$ semen Portland dengan abu terbang. Namun demikian kuat tekan yang dihasilkan pada penggantian abu terbang dengan semen Portland di atas 20\% masih lebih tinggi dibandingkan dengan tanpa abu terbang, baik pada umur 28 hari dan 56 hari.

kuat tekan beton ringan cenderung mengalami peningkatan seiring dengan bertambahnya umur beton, baik yang menggunakan abu terbang maupun tanpa abu terbang. Beton dengan umur 56 hari lebih tinggi nilai kuat tekannya dibandingkan dengan beton umur 28 hari.

Beton ringan dengan persentase penggunaan $0,4 \%$ superplasticizer memilki kuat tekan yang lebih tinggi dibandingkan dengan persentase $0,8 \%$ superplasticizer. Hal ini terjadi baik pada beton ringan, umur 28 hari maupun 56 hari.

Kuat tekan yang dihasilkan pada penggantian $20 \%$ semen Portland dengan abu terbang dengan $0,4 \%$ dan $0,8 \%$ superplasticizer adalah $14,34 \mathrm{MPa}$ dan 13,97 MPa pada umur 28 hari. Pada umur 56 hari, kuat tekan yang dihasilkan pada penggantian $20 \%$ semen Portland dengan abu terbang dengan $0,4 \%$ dan $0,8 \%$ superplasticizer adalah 18,12 MPa dan 16,23 MPa.

\section{b. Pengujian Modulus Elastisitas Beton}

Pengujian modulus elastisitas beton dilakukan secara simultan dengan pengujian kuat tekan beton yaitu, dengan cara mengukur perpendekan beton pada beban tertentu. Dari data perpendekan beton dapat dihitung regangan beton yang terjadi pada suatu tegangan tertentu.

Tabel 3. Modulus elastisitas rata-rata

\begin{tabular}{|c|c|c|c|c|c|}
\hline $\begin{array}{c}\text { Perlakuan } \\
\text { Beton }\end{array}$ & $\begin{array}{c}28 \text { hari } \\
(\mathrm{MPa})\end{array}$ & $\begin{array}{c}0 \% \\
\text { FA }\end{array}$ & $\begin{array}{c}56 \text { hari } \\
(\mathrm{MPa})\end{array}$ & $\begin{array}{c}0 \% \\
\text { FA }\end{array}$ & $\begin{array}{c}\% \text { umur } \\
28 \text { ke 56 }\end{array}$ \\
\hline $0 \% \mathrm{FA}+0,4 \% \mathrm{SP}$ & 9549,22 & 0 & 10459,55 & 0 & $9,53 \%$ \\
\hline $10 \% \mathrm{FA}+0,4 \% \mathrm{SP}$ & 10408,96 & $9,00 \%$ & 10865,96 & $3,88 \%$ & $4,39 \%$ \\
\hline $20 \% \mathrm{FA}+0,4 \% \mathrm{SP}$ & 10766,71 & $12,74 \%$ & 11006,56 & $5,22 \%$ & $2,22 \%$ \\
\hline $30 \% \mathrm{FA}+0,4 \% \mathrm{SP}$ & 10332,82 & $8,20 \%$ & 10774,60 & $3,01 \%$ & $4,27 \%$ \\
\hline $40 \% \mathrm{FA}+0,4 \% \mathrm{SP}$ & 9886,53 & $3,53 \%$ & 10651,36 & $1,83 \%$ & $7,73 \%$ \\
\hline $0 \% \mathrm{FA}+0,8 \% \mathrm{SP}$ & 9303,74 & 0 & 10416,10 & 0 & $11,95 \%$ \\
\hline $10 \% \mathrm{FA}+0,8 \% \mathrm{SP}$ & 10177,13 & $9,38 \%$ & 10640,36 & $2,15 \%$ & $4,55 \%$ \\
\hline $20 \% \mathrm{FA}+0,8 \% \mathrm{SP}$ & 10338,00 & $11,11 \%$ & 10756,44 & $3,26 \%$ & $4,04 \%$ \\
\hline $30 \% \mathrm{FA}+0,8 \% \mathrm{SP}$ & 10099,23 & $8,55 \%$ & 10506,75 & $0,87 \%$ & $4,03 \%$ \\
\hline $40 \% \mathrm{FA}+0,8 \% \mathrm{SP}$ & 9877,70 & $6,16 \%$ & 10482,07 & $0,63 \%$ & $6,11 \%$ \\
\hline
\end{tabular}

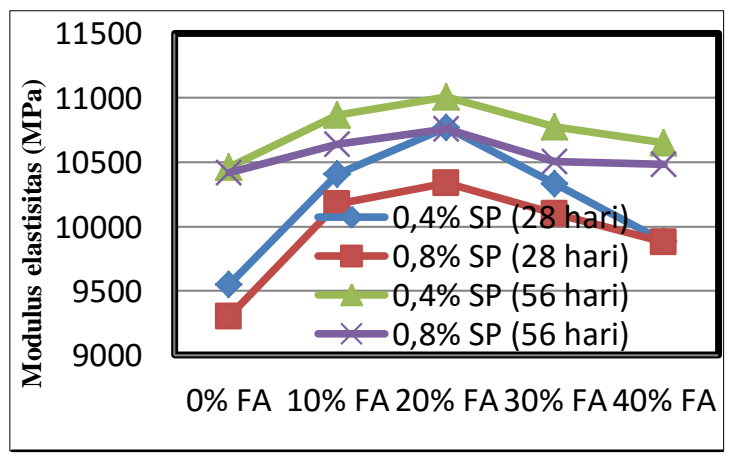

Gambar 4 Modulus elastisitas beton ringan dengan penggantian semen Portland dengan abu terbang

Dari Tabel 3 dan Gambar 4, terlihat bahwa modulus elastisitas meningkat dengan bertambahnya penggantian semen Portland dengan abu terbang. Peningkatan terjadi hingga $20 \%$ penggantian semen Portland dengan abu terbang. Penggantian di atas $20 \%$ 
abu terbang, menyebabkan modulus elastisitas menurun terhadap kuat tekan dengan penggantian 20\% semen Portland dengan abu terbang, namun masih lebih tinggi dibandingkan dengan beton tanpa abu terbang.

Modulus elastisitas mengalami peningkatan dengan bertambahnya umur beton. Modulus elastisitas beton pada umur 56 hari lebih tinggi dibandingkan dengan modulus elastisitas beton pada umur 28 hari.

Beton ringan dengan persentase penggunaan $0,4 \%$ superplasticizer memilki modulus elastisitas yang lebih tinggi dibandingkan dengan persentase $0,8 \%$ superplasticizer. Hal ini terjadi baik pada beton ringan umur 28 hari maupun 56 hari.

Modulus elastisitas yang dihasilkan pada penggantian $20 \%$ semen Portland dengan abu terbang dengan $0,4 \%$ dan $0,8 \%$ superplasticizer adalah $10766,71 \mathrm{MPa}$ dan 10338,00 MPa pada umur 28 hari. Pada umur 56 hari, modulus elastisitas yang dihasilkan pada penggantian 20\% semen Portland dengan abu terbang dengan $0,4 \%$ dan $0,8 \%$ superplasticizer adalah 11006,56 $\mathrm{MPa}$ dan 10756,44 MPa.

\section{Pembahasan}

\section{Nilai slump beton ringan}

Pada penelitian ini menunjukkan bahwa, semakin besar persentase penggantian abu terbang dengan semen Portland untuk beton ringan, maka semakin besar pula nilai slump yang didapat. Hasil yang sama juga didapat oleh (Sudhiartha, 2014).

Menurut (Murdock, 1991), peningkatan nilai slump pada beton ringan akibat penggantian abu terbang dengan semen Portland disebabkan sskarena abu terbang memiliki butiran yang berbentuk bulat serta tekstur yang halus. Butiran halus ini menyebabkan friksi yang terjadi pada adukan menjadi kecil. Pada saat abu terbang dicampurkan ke dalam adukan, abu terbang belum bereaksi dengan air sehingga air hanya bersifat sebagai pelumas. Selebihnya, air akan bercampur dengan semen Portland. Mengingat faktor air semen yang tetap, maka kelebihan yang tidak dipakai oleh bagian semen yang digantikan oleh abu terbang akan menyebabkan adukan menjadi lebih encer dan meningkatnya nilai slump.

Superplasticizer juga memiliki pengaruh terhadap peningkatan nilai slump pada beton ringan. Hal tersebut karena superplasticizer berbentuk cair sehingga jika dicampurkan dalam adukan beton akan menyebabkan semen menjadi terdispersi lebih merata dan menghasilkan nilai slump yang tinggi. Hal ini terlihat dari penelitian, dimana nilai slump meningkat dari persentase $0,4 \%$ hingga $0,8 \%$ superplasticizer, yang berarti workabilitas beton menjadi meningkat seiring dengan penambahan persentase superplasticizer.

\section{Sifat mekanik beton ringan}

Abu terbang yang digunakan dalam penelitian ini, mampu meningkatkan kuat tekan dan modulus elastisitas beton ringan dengan tanpa abu terbang. Hal ini dapat terjadi sebagai akibat dari alumina dan silica aktif (kandungan senyawa kimia dalam abu terbang) yang bereaksi dengan kapur bebas hasil hidrasi semen membentuk Calsium Silikat Hidrat (C$\mathrm{S}-\mathrm{H})$ dan Calsium Aluminat Hidrat (C-A-H) (Reaksi pozzolanik). C-S-H dan C-A-H tambahan dari reaksi pozzolanik meningkatkan properti mekanik pada beton itu sendiri (Salain, 2007). Penurunan kuat tekan dan modulus elastisitas beton ringan dengan penggantian di atas $20 \%$ semen Portland dengan abu terbang, disebabkan karena jumlah alumina dan silica aktif dalam abu terbang telah melampaui jumlah kapur bebas yang tersedia.

Kuat tekan dan modulus elastisitas beton ringan meningkat dari umur 28 hari ke umur 56 hari, pada beton tanpa penggantian abu terbang (0\% abu terbang). Hal ini terjadi karena semen dan air yang saling bereaksi memerlukan waktu lebih lama untuk menghasilkan hidrasi semen.

Persentase superplasticizer sebesar $0,4 \%$ menunjukkan nilai kuat tekan yang lebih tinggi dibandingkan dengan persentase superplasticizer sebesar 0,8\%. Dalam penelitian ini, persentase $0,8 \%$ superplasticizer hanya memberikan peningkatan terhadap nilai slump, tetapi tidak diikuti dengan peningkatan kuat tekan. Penambahan superplasticizer pada persentase yang besar hanya akan memberikan workabilitas yang baik. Superplasticizer akan memberikan peningkatan kuat tekan pada beton, jika digunakan dengan kadar tertentu. Berdasarkan data uji di laboratorium, superplasticizer mengandung kurang lebih $70 \%$ air, sehingga jika digunakan dalam kadar berlebih akan meningkatkan workabilitas namun menurunkan kuat tekan beton ringan.

Nilai kuat tekan maksimum terdapat pada beton dengan penggantian $20 \%$ abu terbang serta $0,4 \%$ superplasticizer yaitu, $18,12 \mathrm{MPa}$ pada umur 56 hari. Hasil ini menunjukkan bahwa beton ringan dapat digolongkan ke dalam beton ringan dengan tujuan struktural, 
karena menghasilkan kuat tekan di atas 17,24 MPa.

\section{SIMPULAN DAN SARAN \\ Simpulan}

Dari penelitian dan pembahasan yang telah dilakukan, dapat diambil simpulan sebagai berikut:

1. Kuat tekan dan modulus elastisitas beton ringan mengalami peningkatan hingga penggantian $20 \%$ semen Portland dengan abu terbang. Penggantian di atas $20 \%$ semen Portland dengan abu terbang, menurunkan kuat tekan dan modulus elastisitas, namun nilai yang dihasilkan masih lebih tinggi dibandingkan dengan beton ringan tanpa abu terbang.

2. Persentase penambahan superplasticizer dari $0,4 \%$ ke $0,8 \%$, mampu meningkatkan slump beton ringan, namun menurunkan kuat tekan dan modulus elastisitas beton ringan.

3. Kuat tekan maksimum terdapat pada penggantian $20 \%$ semen Portland dengan abu terbang dan $0,4 \%$ superplasticizer pada umur 56 hari, yakni sebesar 18,12 MPa. Hasil ini memenuhi standar minimal untuk kuat tekan beton ringaan untuk tujuan struktural.

\section{Saran}

Saran-saran yang diberikan sehubungan dengan penelitian ini adalah sebagai berikut:

1. Penggunaan superplasticizer perlu diperhatikan, untuk menghindari penurunan kuat tekan.

2. Penelitian selanjutnya perlu dikembangkan dengan menggunakan agregat ringan jenis lain untuk menghasilkan kuat tekan dan modulus elastisitas yang lebih tinggi.

\section{DAFTAR PUSTAKA}

Anonim. 1990. SNI T-15-1990-03. Tata Cara Rencana Pembuatan Campuran Beton Normal. Bandung : Badan Standarisasi Nasional.

Anonim. 2002. SNI 03-3449-2002. Tata Cara Perancangan Campuran Beton Ringan dengan Agregat Ringan. Jakarta : Badan Standarisasi Nasional.
Anonim. 2002. SNI 03-2847-2002. Tata Cara Perhitungan Struktur Beton Untuk Bangunan Gedung. Bandung : Badan Standarisasi Nasional.

Anonim. 2004. SNI 15-2049-2004. Semen Portland. Jakarta : Badan Standarisasi Nasional.

Anonim. 2000. SNI 03-2834-2000. Tata Cara Pembuatan Rencana Campuran Beton Normal. Jakarta : Badan Standarisasi Nasional.

Anonim. 2002. SNI 03-2461-2002. Spesifikasi Agregat Ringan Untuk Beton Struktural. Jakarta : Badan Standarisasi Nasional.

ASTM. 1995. ASTM C469. Standar Test Method For Static Modulus of Elasticity and Poisson's Ratio of Concrete in Compression. Philadelphia.

ASTM. 1995. ASTM 494. Concrete and Aggregates. Philadelphia.

Akmaluddin. 2009. "Pengaruh Ukuran Batu Apung Terhadap Sifat Mekanik Beton Ringan”. Seminar Nasional dan Pameran Hasil-Hasil Penelitian. Mataram 29-30 September.

Asroni, A. 2010. Balok dan Pelat Beton Bertulang. Edisi I. Surakarta : Graha Ilmu. Hal : 2-3.

Dobrowolski. J.A. $1993 . \quad$ Concrete Constuction. McGraw-Hill : New York.

Hidayat. 2003. "Studi Banding Pengaruh Faktor Air Semen dan Kadar Fly Ash Terhadap Kuat Tekan dan Permeabilitas Beton Ringan" (tesis). Available from : URL : http//lontar.ui.ac.id. Depok : Universitas Indonesia.

Lea, F.M. 1970. The Chemistry of Cement and Concrete. Third Edition. London : Edward Arnold Ltd.

Maryoto, A. 2008. "Pengaruh Penggunaan High Volume Fly Ash Pada Kuat Tekan Mortar"(jurnal). Purwokerto : Universitas Jenderal Sudirman. Jurnal Teknik Sipil dan Perencanaan No 2 Vol 10. Hal 103114.

Mardiono. 2011. "Pengaruh Pemanfaatan Abu Terbang (fly ash) Dalam Beton Mutu Tinggi"(Tugas Akhir). Jakarta : Universitas Guna Dharma.

Mehta, P.K. 1986. Concrete Structure Properties and Material. New Jersey : Englewood Cliffs.

Mulyono, T. 2003. Teknologi Beton. Edisi Kedua. Andi Offset. Hal : 99, 120-124.

Nawy. E.G. 1990. Reinforce Concrete a Fundamental Approach Terjemahan. Cetakan Pertama. Bandung : PT. Eresco. 
Neville, A.M and Brooks, J.J. 1998. Concrete Technology. Singapore : Longman.

PEDC. 1987. Teknologi Bahan 3. Edisi Kedua. Bandung : PEDC.

Salain, I.M.A.K., Giri, I.B.D., dan Saraswati, M.A.A. 2011. Pemanfaatan Abu Terbang Dalam Jumlah Besar Pada Pembuatan Beton. Prosiding Seminar Nasional AvoER ke 3. Palembang 26-27 Oktober.

Salain, I.M.A.K. 2007. Perbandingan Kuat Tekan dan Permeabilitas Beton Yang Menggunakan Semen Portland Pozzolan Dengan Yang Menggunakan Semen Portland Tipe I. Seminar dan Pameran HAKI 2007.

Saputra, A.I. 2010. "Pengaruh Jumlah Sambungan Terhadap Kapasitas Kolom Pracetak Beton Ringan dari Batu Apung" (tugas akhir). Mataram : Unram.

Sebayang, S. 2010. "Pengaruh Kadar Abu Terbang Sebagai Pengganti Sejumlah Semen Pada Beton Alir Mutu Tinggi”'(jurnal). Lampung : Universitas Lampung. Jurnal Rekayasa Sipil Vol 14 No 1.

Suseno, H., Wahyuni, E., dan Hariono, B. 2008. "Pengaruh Variasi Proporsi Campuran dan Penambahan Superplasticizer Terhadap Berat Isi, dan Kuat Tekan Beton Ringan Struktural Beragregat Batuan Andesit Piroksen"(jurnal). Malang : Universitas Brawijaya. Jurnal Rekayasa Sipil Vol 2 No 3-ISSN 1978-5658.

Sudhiarta, T.A. 2014. "Perilaku Mekanis Beton Kinerja Tinggi Dengan Variasi Penggunaan Abu Terbang Sebagai Pengganti Sebagian Semen"(tesis). Denpasar : Universitas Udayana.

Wibawa, T.K. 2011. Imajinatif Rekayasa. Available from : URL : http//tatangw.blogspot.com. 